\title{
Targeting of the Prion Protein to the Cytosol: Mechanisms and Consequences
}

\section{Margit Miesbauer, Angelika S. Rambold", Konstanze F. Winklhofer* and Jörg Tatzelt ${ }^{*}$}

German Center for Neurodegenerative Diseases (DZNE) Munich \& Adolf-Butenandt-Institute, Neurobiochemistry, Ludwig-Maximilians-University Munich, Schillerstrasse 44, D-80336 München, Germany

\#present address: Cell Biology and Metabolism Program, National Institute of Child Health and Human Development, National Institutes of Health, Bethesda, Maryland, USA

\begin{abstract}
Prion diseases are characterized by the conformational transition of the cellular prion protein $\left(\mathrm{PrP}^{\mathrm{C}}\right)$ into an aberrant protein conformer, designated scrapie-prion protein $\left(\mathrm{PrP}^{\mathrm{Sc}}\right)$. A causal link between protein misfolding and neurodegeneration has been established for a variety of neurodegenerative disease, such as Alzheimer's disease, Parkinson's disease and polyglutamine diseases, but there is an ongoing debate about the nature of the neurotoxic species and how non-native conformers can damage neuronal populations. PrP is normally imported into the endoplasmic reticulum (ER) and targeted to the outer leaflet of the plasma membrane via a glycosylphosphatidylinositol (GPI) anchor. However, several conditions, such as ER stress or some pathogenic mutations in the PrP gene, can induce the mislocalization of PrP in the cytosol, where it has a neurotoxic potential as demonstrated in cell culture and transgenic mouse models. In this review we focus on intrinsic factors and cellular pathways implicated in the import of PrP into the ER and its mistargeting to the cytosol. The findings summarized here not only reveal a complex regulation of the biogenesis of PrP, but also provide interesting new insight into toxic activities of pathogenic protein conformers and quality control pathways of ER-targeted proteins.
\end{abstract}

\section{Introduction}

Prion diseases are a group of transmissible neurodegenerative disorders including Creutzfeldt-Jakob disease (CJD) and Gerstmann-Sträussler-Scheinker syndrome (GSS) in humans, scrapie in sheep and goat, bovine spongiform encephalopathy (BSE) in cattle and chronic wasting disease (CWD) in free-ranging deer. A hallmark of prion diseases is the conversion of the cellular prion protein $\mathrm{PrPC}^{\mathrm{C}}$ into its misfolded isoform, termed $\mathrm{PrPSc}$. Similarly to other neurodegenerative diseases, there is an ongoing debate whether folding intermediates, oligomers, amorphous or fibrillar aggregates are the neurotoxic species (rev. in (Caughey and Lansbury, 2003; Haass and Selkoe, 2007; Winklhofer et al., 2008). A unique feature of prion diseases is their transmissibility, which is also linked to $\mathrm{PrP}^{\mathrm{Sc}}$ constituting the main component of infectious prions

*Konstanze.Winklhofer@med.uni-muenchen.de Joerg.Tatzelt@med.uni-muenchen.de (reviewed in Aguzzi and Polymenidou, 2004; Chesebro, 2003; Collinge, 2001; Prusiner et al., 1998; Weissmann et al., 1996). In the majority of prion diseases there is a correlation between the accumulation of misfolded PrP, formation of infectious prions and neurodegeneration, however, there are some interesting exceptions. Transgenic mouse models revealed that several PrP mutants can induce neuronal cell death in the absence of infectious prion propagation (Baumann et al., 2007; Chiesa et al., 1998; Flechsig et al., 2003; Hegde et al., 1998; Li et al., 2007; Ma et al., 2002; Muramoto et al., 1997; Shmerling et al., 1998). Vice versa it has been shown that propagation of infectious prions can occur in the absence of clinical signs (Brandner et al., 1996; Chesebro et al., 2005; Mallucci et al., 2003). Consequently, it appears plausible that the infectious particle and the neurotoxic agent might be two distinct species/conformers.

In this review we focus on a specific class of pathogenic PrP conformers that are characterized by a toxic potential in the cytosolic compartment. We summarize our current knowledge about PrP domains and cellular pathways regulating the translocation of PrP into the ER and pathophysiological consequences of PrP accumulation in the cytosol.

\section{PrP-mediated neurodegeneration: a cytosolic connection}

Several studies indicated that PrP can acquire a neurotoxic potential when its import into the ER is partially or completely compromised. Employing in vitro models Lingappa and coworkers demonstrated that during import into the ER, PrP can attain two different transmembrane topologies with either the $\mathrm{N}$ - or C-terminal domain facing the cytosol (Yost et al., 1990) (see below). A transgenic mouse model revealed that preventing the import of PrP into the ER leads to the formation of a neurotoxic PrP species in the cytosol. Mice expressing a PrP mutant lacking the $\mathrm{N}$-terminal ER targeting signal (cytoPrP) acquired severe ataxia due to rapid cerebellar granule neuron degeneration (Ma et al., 2002). A recent study supported this activity of cytoPrP and demonstrated that neurotoxicity of cytoPrP is also seen in different neuronal populations (Wang et al., 2009). Cytotoxic effects of cytoPrP were also observed in several mammalian cell culture models (Ma et al., 2002; Rambold et al., 2006; Rane et al., 2004). Further support for a toxic potential of cytosolically localized PrP was obtained in a yeast model. During post-translational targeting of $\operatorname{PrP}$ to the ER, PrP was missorted to the cytosol and interfered with yeast growth (Heller et al., 2003).

So far, mutations within the $\mathrm{N}$-terminal signal sequence of $\operatorname{PrP}$, which could affect the efficiency of ER import, have not been identified in patients suffering from prion diseases. However, the pathogenic PrP-W145Stop mutant, linked to Gerstmann-Sträussler-Scheinker syndrome in humans, has been reported to localize to the cytosolic and nuclear compartment (Zanusso et al., 1999). A different study including another pathogenic mutant, PrP-Q160Stop, 
corroborated these findings and provided the first evidence that information in the $\mathrm{C}$-terminal domain of $\mathrm{PrP}$ is necessary and sufficient for ER import (Heske et al., 2004) (see below).

\section{Quality control of secretory proteins}

As outlined above, alterations in protein folding, processing and/or degradation are common features of prion diseases as well as other neurodegenerative disorders, implying a role of quality control systems, such as molecular chaperones and the ubiquitin-proteasome pathway in the removal of neurotoxic protein conformers (rev. in (Ciechanover and Brundin, 2003; Morimoto, 2008). In the cytosol the ubiquitin-proteasome system (UPS) is the main pathway for regulated protein turnover (rev. in (Ciechanover et al., 2000; Hershko and Ciechanover, 1998; Pickart, 2001). Moreover, the proteasome mediates post-translational degradation of non-native proteins generated in the ER as part of a quality control system, designated ER-associated degradation (ERAD). This pathway involves recognition of non-native polypeptides by ER-resident chaperones and retrograde transport to the cytosol where proteasomal degradation occurs (rev. in (Ellgaard and Helenius, 2003; Meusser et al., 2005; Nakatsukasa and Brodsky, 2008). In case ERAD substrates accumulate in the ER lumen, intracellular signaling pathways are induced, collectively called the unfolded protein response (UPR) (rev. in (Malhotra and Kaufman, 2007; Ron and Walter, 2007). Only little is known about quality control pathways of GPI-anchored proteins, such as PrP. Interestingly, a pre-emptive, co-translocational quality control pathway was described recently, which operates before translocation into the ER is completed (Kang et al., 2006; Oyadomari et al., 2006). Regulated translocation could act as an early quality control step to prevent an overload of the ER with non-native proteins, specifically during an imbalance in cellular homeostasis. Indeed, it has been shown that PrP can be co-translocationally re-directed to proteasomal degradation during conditions of acute ER stress (Kang et al., 2006; Orsi et al., 2006).

\section{Import of PrP into the endoplasmic reticulum: the role of PrP domains}

\section{The N-terminal ER signal sequence}

The primary signal to target PrP to the ER is a N-terminal signal sequence (aa 1-22), which is recognized and bound by the signal recognition particle (SRP). SRP interaction with both the emerging polypeptide chain and the ribosome results in pausing of elongation and targeting of the ribosome-nascent chain complex to the Sec61 translocon. After binding of SRP to its receptor at the ER membrane, protein synthesis proceeds and transfer of the polypeptide chain into the ER lumen occurs in a co-translational manner (Gilmore et al., 1982a; Gilmore et al., 1982b; Meyer and Dobberstein, 1980; Walter and Blobel, 1980; Walter and Blobel, 1982; Walter et al., 1984).

ER import can be mediated by a remarkably diverse set of signal sequences, and it has been demonstrated for various secretory pathway proteins that translocation efficiency is regulated in a signal peptide sequence-specific manner (rev. in (Hegde and Bernstein, 2006; Martoglio and Dobberstein, 1998; von Heijne, 1985). Indeed, the sequence of the ER signal peptide has a significant impact on the import efficiency and the formation of topological isoforms of PrP. The first hint that PrP can be synthesized in topologies others than the GPI-anchored form emerged from in vitro studies (Yost et al., 1990). Two different topologies, termed ${ }^{\mathrm{Ntm}} \mathrm{PrP}$ (N-terminus facing the ER lumen) or ${ }^{\mathrm{Ctm} P r P}$ (C-terminus facing the ER lumen) were described with the internal hydrophobic (HD) domain (amino acids 112 - 135) serving as a putative transmembrane domain. Mutations within the internal HD or the N-terminal signal peptide were found to alter the relative amount of ${ }^{\mathrm{Ctm} P r P}$ and NtmPrP (Hegde et al., 1998; Kim et al., 2001; Stewart et al., 2001). Interestingly, increased synthesis of CtmPrP has been shown to coincide with progressive neurodegeneration both in Gerstmann-Sträussler-Scheinker syndrome (GSS) patients with an $\mathrm{A} 117 \mathrm{~V}$ mutation and in transgenic mice carrying a triple mutation within the hydrophobic domain (AAA113,115,118VVV, in short AV3) (Hegde et al., 1998; Stewart et al., 2005). For a more detailed description of CtmPrP and other neurotoxic PrP mutants, please see the review by Harris and colleagues in the same issue.

The role of the ER signal sequence and the HD in the ER import efficiency of PrP was further emphasized when we expressed mammalian PrP in Saccharomyces cerevisiae. Due to the relatively low hydrophobicity index (Kyte-Doolittle) of the signal peptide, PrP was targeted to the ER via a post-translational pathway in yeast cells. As a consequence, ER import was impaired and the accumulation of $\operatorname{PrP}$ in the cytosol interfered with cell viability. By using a more hydrophobic signal peptide or by deleting the HD, import of PrP into the ER as well as and yeast growth could be restored (Heller et al., 2003).

The internal hydrophobic domain (HD)

The internal HD (aa 112-135) of PrP was first described as a putative transmembrane domain (Lopez et al., 1990). Later it was shown that mutations within the $\mathrm{HD}$ can alter the relative amount of ${ }^{\mathrm{Ctm} P r P}$ and ${ }^{\mathrm{N} t m} \mathrm{PrP}$ (Hegde et al., 1998; Kim et al., 2001; Stewart et al., 2001). Moreover, different models revealed that this stretch of hydrophobic amino acids has additional properties: 1 . Short peptides comprising amino acid residues 106-126 form fibrils in vitro (Tagliavini et al., 1993) and induce cell death in cultured cells (Brown et al., 1996; Deli et al., 2000; Forloni et al., 1993; Haïk et al., 2000). 2. In polarized cells the HD confers basolateral sorting in a dominant manner (Uelhoff et al., 2005). 3. Transgenic mice expressing PrP mutants lacking the HD (PrP $\Delta \mathrm{HD})$ spontaneously develop a non-transmissible neurodegenerative disease (Baumann et al., 2007; Li et al., 2007; Shmerling et al., 1998). 4. The HD is linked to the toxic activity of cytosolically localized PrP (Rambold et al., 2006) (see below). Moreover, we have recently shown that the HD promotes dimer formation of $\mathrm{PrP}$, which is associated with its stress-protective activity (Rambold et al., 2008).

\section{The C-terminal GPI signal peptide}

Biochemical studies using purified $\mathrm{PrP}^{\mathrm{Sc}}$ revealed that $\mathrm{PrP}$ is modified with a glycosylphosphatidylinositol (GPI) anchor (Stahl et al., 1987). GPI modification occurs in the ER via removal of a C-terminal signal peptide and the replacement with a pre-formed GPI anchor at an acceptor amino acid, called $\omega$ site. This reaction is catalyzed by a transamidase that resides within the ER membrane (Amthauer et al., 1993; Eisenhaber et al., 1998; Englund, 1993; Udenfriend and 
A
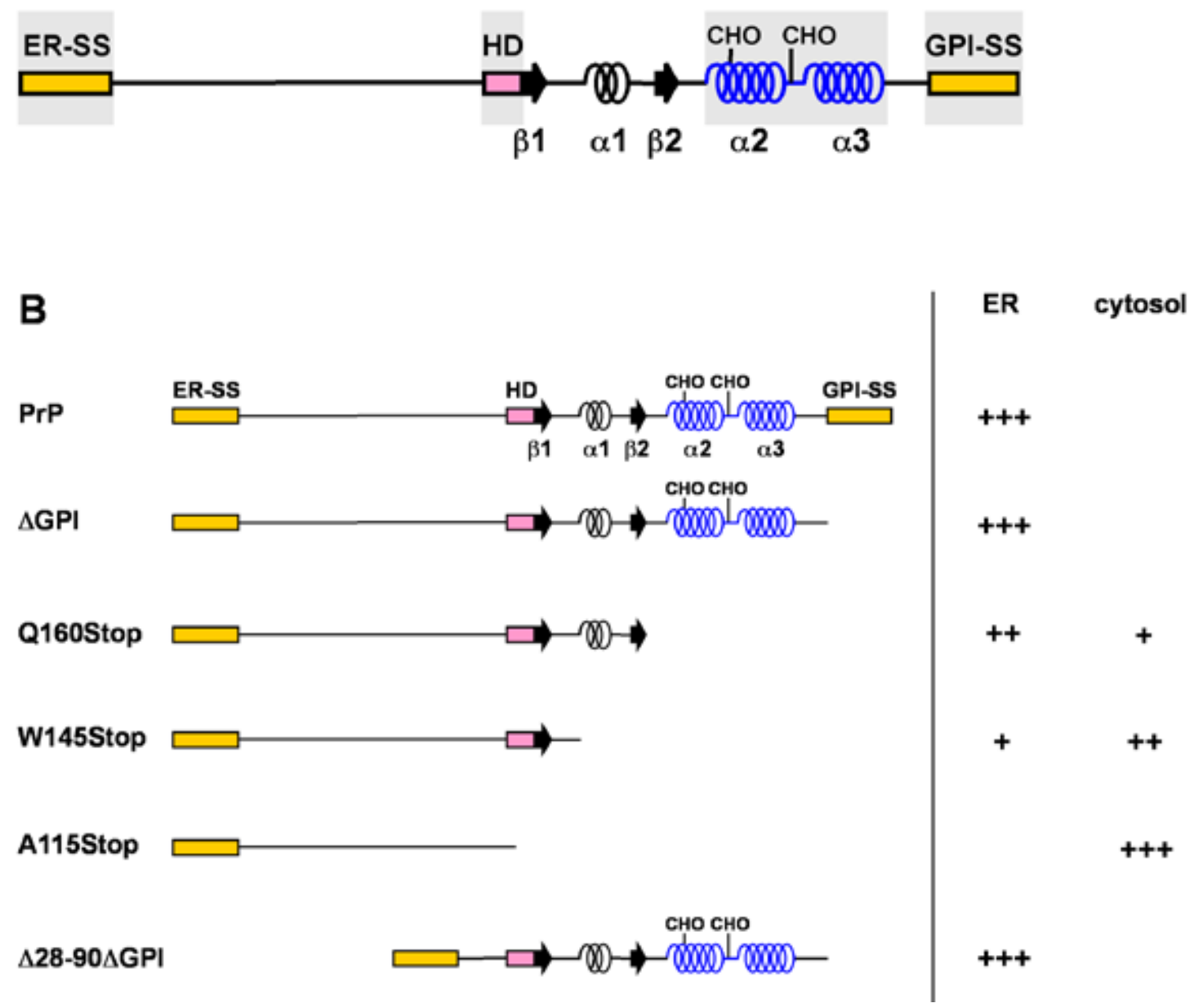

Figure 1. (A) Schematic presentation of the mammalian prion protein. ER-SS: ER signal sequence, $\alpha 1-3$ : $\alpha$-helical regions, $\beta 1,2$ : $\beta$-strands, CHO: N-linked glycosylation acceptor site, GPI-SS: GPI anchor signal sequence, straight line: unstructured regions. Gray boxes mark domains implicated in the import of PrP into the ER. (B) The C-terminal structured domain is necessary and sufficient for effcient translocation into the ER. The scheme illustrates the ER import efficiency of different $\operatorname{PrP}$ mutants with deletions in the $\mathrm{C}$ - or $\mathrm{N}$-terminal domain. While a deletion of the unstructured $\mathrm{N}$-terminus and/or of the $\mathrm{C}$-terminal GPI anchor signal sequence ( $\operatorname{PrP} \Delta \mathrm{GPI}, \operatorname{PrP} \Delta \mathrm{N} \Delta \mathrm{GPI}$ ) does not impair translocation of $\operatorname{PrP}$ the import efficiency successively decreased by increasing the deletions in the $\mathrm{C}$-terminal structured domain.

Kodukula, 1995). Similarly to the N-terminal signal peptides, the C-terminal GPI anchor signal sequences do not share conserved consensus sequences but rather characteristic features. Only a few amino acids with small side chains are allowed at the $\omega$, the $\omega+1$ and the $\omega+2$ positions, and a hydrophobic domain is required about 10-12 amino acids distal to the $\omega$ site (Ferguson and Williams, 1988; Kodukula et al., 1993; Moran et al., 1991; Nuoffer et al., 1993; Nuoffer et al., 1991).

Deletion of the C-terminal GPI anchor signal sequence prevents membrane attachment of PrP $\Delta$ GPI (also known as PrP-S230X or GPI-PrP), but does not interfere with ER import or further trafficking of $\operatorname{PrP} \Delta \mathrm{GPI}$ through the secretory pathway (Blochberger et al., 1997; Rogers et al., 1993; Winklhofer et al., 2003). PrP $\Delta$ GPI is secreted both by cultured cells (Winklhofer et al., 2003) and by neurons of transgenic mice (Chesebro et al., 2005). However, membrane anchoring of $\operatorname{PrP}$, be it via the authentic GPI anchor or via a heterologous CD4 transmembrane domain is required to ensure efficient modification of $\mathrm{PrP}$ with $\mathrm{N}$-linked glycans of complex structure (Winklhofer et al., 2003).

Interestingly, the C-terminal GPI anchor signal peptide has been reported to mediate targeting of $\operatorname{PrP}$ to the ER. Initial results obtained in vitro indicated that the C-terminal signal peptide can promote post-translational translocation of PrP into the ER (Holscher et al., 2001). These findings were recently corroborated in cultured cells, moreover, it was shown that the GPI signal sequence can mediate cotranslational ER targeting when located at the $\mathrm{N}$-terminus of PrP or heterologous proteins (Gu et al., 2008).

The structured C-terminal domain

Structural studies on recombinant PrP indicated a particular modular composition (Figure $1 \mathrm{~A}$ ): the $\mathrm{N}$-terminal domain of 
PrP spanning 120 amino acids is flexibly disordered followed by a highly structured C-terminal domain of approximately 110 amino acids. This autonomously folding domain contains three $\alpha$-helical regions and a short, two-stranded $\beta$-sheet (Donne et al., 1997; Riek et al., 1996; Riek et al., 1997). The analysis of PrP-W145Stop, a pathogenic PrP mutant linked to Gerstmann-Sträussler-Scheinker syndrome in humans, provided the first hint that a loss of the C-terminal domain interferes with ER import of PrP: PrP-W145Stop was found in the cytosolic and nuclear compartment (Zanusso et al., 1999). Further studies including a different pathogenic mutant, PrP-Q160Stop, corroborated these findings and revealed that information in the $\mathrm{C}$-terminal domain of $\mathrm{PrP}$ is necessary and sufficient for its import into the ER (Heske et al., 2004). We could now show that it is the presence of alpha-helical domains in the C-terminus that promotes ER import of PrP. The study revealed that after targeting to the translocon the secondary structure of the nascent polypeptide chain can significantly modulate translocation efficiency. ER-targeted polypeptides dominated by unstructured domains failed to efficiently translocate into the ER lumen and were subjected to proteasomal degradation via a co-translocational/pre-emptive pathway (Miesbauer et al., 2009).

\section{Toxic PrP conformers in the cytosol}

\section{cytoPrP}

Aconvincing model to demonstrate the neurotoxic capacity of cytosolically localized PrP (cytoPrP) was initially generated by Lindquist and coworkers: Mice expressing a PrP mutant with a deleted $\mathrm{N}$-terminal ER targeting signal sequence acquire severe ataxia due to cerebellar degeneration (Ma et al., 2002). Importantly, in a different transgenic mouse model toxicity of cytoPrP was also demonstrated in other neuronal populations (Wang et al., 2009). Cell culture studies indicated that toxicity of cytoPrP seems to be dependent on its association with intracellular membranes (Wang et al., 2006) and its binding to Bcl-2, an anti-apoptotic protein present at the cytosolic side of ER and mitochondrial membranes (Rambold et al., 2006). Brain extracts from clinically ill transgenic mice expressing cytoPrP do not contain infectious prions, a phenomenon also seen in other transgenic mouse models of neurotoxic PrP mutants (rev. in (Winklhofer et al., 2008). In this context it should also be noted that cytosolically localized PrP seems to be present in a subset of neurons even under physiological conditions (Mironov et al., 2003).

PrPSc

The scrapie-prion protein or $\mathrm{PrPSc}^{\mathrm{Sc}}$ was originally identified as a protease-resistant protein in brain extracts that copurifies with the infectious scrapie agent (Bolton et al., 1982). In contrast to $\mathrm{PrP}^{\mathrm{C}}, \mathrm{PrP}^{\mathrm{Sc}}$ is insoluble in non-ionic detergents, partially resistant to proteolytic digestion and characterized by a high content of $\beta$-sheet secondary structure (Caughey et al., 1991; Meyer et al., 1986; Pan et al., 1993). While PrPSc seems to be sufficient for the formation of infectious prions, elegant grafting experiments provided the first evidence that $\mathrm{PrPSc}^{\mathrm{Sc}}$ is not toxic to neurons lacking $\mathrm{PrP}^{\mathrm{C}}$ (Brandner et al., 1996), a finding later supported by conditional cell-type specific PrP knockout mice (Mallucci et al., 2003) and transgenic mice expressing $\operatorname{PrP} \Delta \mathrm{GPI}$, an anchorless PrP mutant (Chesebro et al., 2005). We have recently established a new cell culture model, which corroborates the observations from the mouse models and supports the notion that $\mathrm{PrP}^{\mathrm{Sc}}$ is only toxic to cells expressing $\operatorname{PrP}^{\mathrm{C}}$ (Rambold et al., 2008). Based on these findings, two plausible scenarios for the toxic effects of $\mathrm{PrP}^{\mathrm{Sc}}$ can be envisaged, which are not mutually exclusive: Either neurotoxicity of $\mathrm{PrP}^{\mathrm{Sc}}$ is linked to its propagation in neuronal cells, which is dependent on the expression of $\mathrm{PrP}^{\mathrm{C}}$, and/or $\mathrm{PrP}^{\mathrm{Sc}}$ elicits a deadly signal through a $\mathrm{PrP}^{\mathrm{C}}$ dependent signaling pathway. Employing mouse models, cell culture and in vitro approaches, Tabrizi and colleagues provided support for the notion that during a prion infection misfolded PrP can translocate into the cytosol of the infected cells and induce toxic effects by inhibiting the proteasome (Kristiansen et al., 2007).

\section{ER-targeted PrP can be re-directed to the cytosol via a co-translocational pathway}

The cytosolic localization of ER proteins is usually linked to a cellular quality control system involving retrograde transport and subsequent proteasomal degradation, designated ERassociated degradation (ERAD). This pathway is designed to ensure cellular homeostasis and to preclude toxic effects of aberrant protein conformers within the ER. The accumulation of $\mathrm{PrP}$ in the cytosol after prolonged inhibition of proteasomal activity was initially interpreted as evidence for retrograde transport of $\mathrm{PrPC}^{\mathrm{C}}$ from the $\mathrm{ER}$ lumen into the cytosol (Ma and Lindquist, 2001; Yedidia et al., 2001). This conclusion, however, was discussed controversially after cytosolic accumulation of $\operatorname{PrP}$ has been proposed to be an experimental artifact, due to the prolonged treatment of cells with proteasomal inhibitors and overexpression of PrP driven by a viral promotor (Drisaldi et al., 2003). Based on our studies in yeast and mammalian cells we proposed that impaired ER import rather than retrograde translocation from the ER is responsible for the formation of cytosolic PrP (Heller et al., 2003; Heske et al., 2004; Tatzelt and Winklhofer, 2004) (Figure 1B). This concept was substantiated by recent studies showing that in addition to ERAD a co-translocational or pre-emptive quality control pathway exists, which interferes with the translocation of secretory pathway proteins into the ER lumen (Kang et al., 2006; Oyadomari et al., 2006). As a consequence, such a co-translocation quality control pathway reduces the amount of non-native substrates in the ER lumen and thereby unburdens the luminal ER quality control machinery. This could be particularly beneficial under conditions of ER stress in order to reduce the ER protein folding load (Kang et al., 2006).

Support for the idea that PrP is targeted via a cotranslocational pathway to the cytosol was the observation that the cytosolic PrP fraction contained an uncleaved signal peptide (Heske et al., 2004; Miesbauer et al., 2009; Rambold et al., 2006; Zanusso et al., 1999). Processing of the $\mathrm{N}$-terminal signal peptide and the transfer of core glycans occur co-translocationally prior to the release of the polypeptide into the ER lumen (rev. in (Kornfeld and Kornfeld, 1985). Thus, an uncleaved signal peptide is indicative for an abrogated translocation event. Interestingly, an uncleaved signal peptide was also described for CtmPrP (Kim and Hegde, 2002; Stewart et al., 2001). Moreover, it has been shown that an uncleaved signal peptide is a 


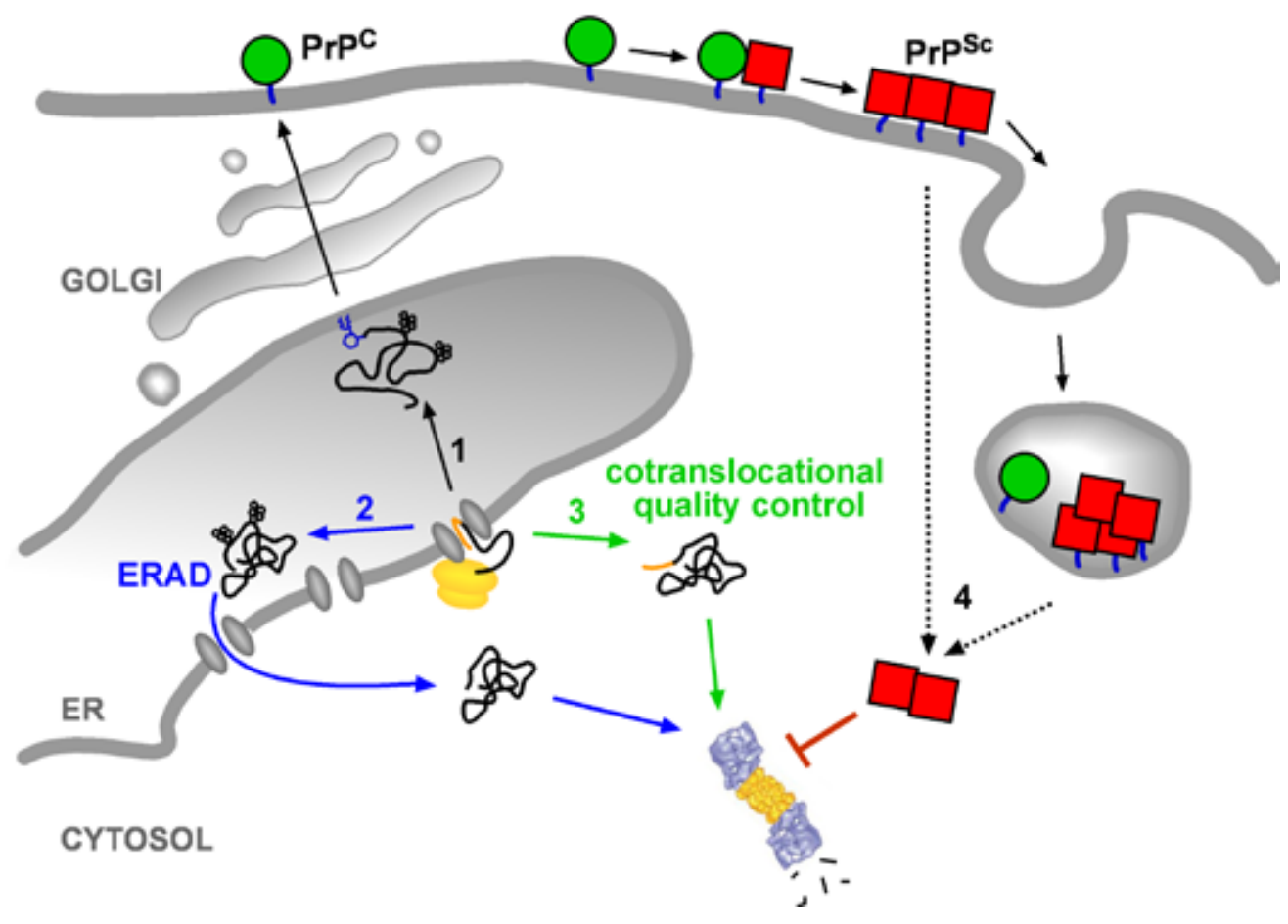

Figure 2. Pathways implicated in the fomation of cytosolically localized PrP. After targeting of the ribosome-nascent chain complex to the translocon the N-terminal signal peptide initiates the translocation process. 1: Under physiological conditions $\mathrm{PrP}$ is translocated into the ER lumen. During import the $\mathrm{N}$-terminal signal peptide is cleaved off and two $\mathrm{N}$-linked glycans are attached. Shortly after release into the ER lumen the C-terminal signal sequence is removed and replaced with a preformed GPI anchor. During transit through the secretory pathway the core glycans are converted into complex structures and $\mathrm{PrP}^{\mathrm{C}}$ is finally targeted to the outer leaflet of the plasma membrane. In scrapie-infected cells, PrPC at the cell surface or along the endocytic pathways interacts with and is converted into PrPSc. 2: The classical ERAD pathway would involve retrotranslocation of non-native or misfolded conformers of PrP present in the ER lumen into the cytosol. The N-linked glycans are removed by a cytosolic $\mathrm{N}$-glycanase prior to proteasomal degradation. 3: In a co-translocational quality control pathway productive translocation of the growing polypetide chain into the ER is not pursued. Instead the protein is directly targeted to proteasomal degradation. Proteins subjected to this pathway would retain their N-terminal signal peptide. 4: In scrapieinfected cells oligomeric species of $\mathrm{PrP}^{\mathrm{Sc}}$ might translocate from the plasma membrane or endocytic compartments to the cytosol where they interfere with proteasomal activity.

characteristic feature of other substrates subjected to the co-translocational/pre-emptive pathway (Oyadomari et al., 2006; Rutkowski et al., 2007).

Why is it interesting that PrP seems to be subjected to a co-translocational quality control pathway? Little is known about quality control pathways of non-native or misfolded GPI-anchored proteins and ERAD in mammalian cells has mainly been studied with transmembrane proteins. Indeed, experimental evidence suggests that PrP is a poor ERAD substrate. In particular, PrP lacking a GPI anchor is misfolded and incompletely glycosylated, however, it is efficiently transported through the secretory pathway and finally secreted (Blochberger et al., 1997; Chesebro et al., 2005; Rogers et al., 1993; Walmsley et al., 2001; Winklhofer et al., 2003). This observation suggests that PrP $\Delta$ GPI is not sensed as misfolded by the cellular quality control systems in the ER lumen. Two observations support such a hypothesis. Firstly, the terminal glucose residues are removed from the core glycans of $\operatorname{PrP} \Delta \mathrm{GPI}$ and secondly, even the overexpression of $\operatorname{PrP} \Delta \mathrm{GPI}$ does not result in the activation of the unfolded protein response (UPR) (Winklhofer et al.,
2003). A recent study supports the idea that misfolded conformers of PrP generated in the ER lumen are neither recognized by ER quality control pathways nor routed to ERAD. Instead, mutant PrPs trafficked to the Golgi, from where the misfolded subpopulation was selectively trafficked for degradation in acidic compartments (Ashok and Hegde, 2009).

Which conditions might impair the import of PrP into the ER? Regarding the ER import mechanism, it is important to note that translocation of PrP into the ER seems to be more complex than that of other secretory proteins. In vitro studies using reconstituted lipid vesicles revealed that ER import of PrP requires the translocon-associated protein (TRAP) complex in addition to the essential translocon components Sec61 complex, the signal recognition particle receptor and the translocating chain associated protein (TRAM) (Fons et al., 2003). Consistent with the idea that an imbalance of cellular homeostasis brings a co-translocational quality control pathway on the scene (Rutkowski et al., 2007), the accumulation of cytosolic PrP containing an uncleaved signal peptide was favored under conditions of ER stress (Kang et al., 2006; Orsi et al., 2006). 


\section{Pathophysiological consequences of cytosolically localized PrP}

A transgenic mouse model and various cell culture approaches provided convincing evidence that cytosolic PrP can have a toxic potential, however, two major questions have remained unanswered. First, does cytosolic PrP play a role in the pathogenesis of prion diseases and second, how does PrP in the cytosol induce neuronal cell death?

In this context it is important to remember that cytoPrP is biochemically quite different from infectious $\mathrm{PrPSc}$. CytoPrP does adopt a misfolded and partially proteinase $\mathrm{K}$ (PK)-resistant conformation, however, it lacks posttranslational modifications, like the GPI anchor and N-linked carbohydrates. Moreover, it does not seem to be infectious. A similar biochemical signature was described for $\operatorname{PrP} \Delta \mathrm{GPI}$. However, PrP $\Delta$ GPI is efficiently imported into the ER and has no toxic activity in cultured cells (Rambold et al., 2006) nor does it cause neurodegeneration in transgenic mice (Chesebro et al., 2005). Based on these findings we established a cell culture model to identify cellular components linked to the toxic activity of cytoPrP (Rambold et al., 2006). Interestingly, an interaction of PrP and Bcl-2 was described previously for recombinantly expressed proteins (Kurschner and Morgan, 1995, 1996). We could verify such an interaction in neuronal cells and showed that the recruitment of $\mathrm{Bcl}-2$ to misfolded PrP provides a plausible explanation for the toxic potential of cytoPrP (Rambold et al., 2006). A different study revealed that toxicity of cytoPrP seems to be dependent on its association with intracellular membranes (Wang et al., 2006), the locale where $\mathrm{Bcl}-2$ resides. Regarding the role of $\mathrm{Bcl}-2$ in cytoPrPmediated toxicity, two scenarios are conceivable. Bcl-2 may be inactivated by its sequestration into cytoPrP aggregates. In support of this possibility, recent results from our group indicated that cytoPrP can displace Bax from a Bcl-2/Bax complex (Rambold et al, unpublished results). Alternatively, binding of $\mathrm{Bcl}-2$ to cytoPrP may induce a conformational change of $\mathrm{Bcl}-2$, converting it into a pro-apoptotic protein. Evidence for opposing phenotypes of $\mathrm{Bcl}-2$ was provided by Lin et al., who showed that the interaction with Nurr77 converts $\mathrm{Bcl}-2$ from a protector to a killer protein (Lin et al., 2004).

Two additional findings need to be considered in the context of cytoPrP-induced toxicity. First, binding of $\mathrm{Bcl}-2$ to $\operatorname{PrP}$, as well as the toxic potential of cytoPrP could be mitigated by the increased expression of $\mathrm{Hsp} 70$ and its cochaperone Hsp40, indicating a protective role of chaperones in PrP-induced toxicity (Rambold et al., 2006). Second, several cell culture models indicated that toxicity of cytoPrP is markedly enhanced under conditions of proteasomal impairment, suggesting that under physiological conditions the accumulation of cytoPrP is efficiently controlled (Ma et al., 2002; Rambold et al., 2006; Rane et al., 2004; Wang et al., 2005; Yedidia et al., 2001). This multifaceted influence on the formation and clearance of cytoPrP, which seems to be highly dependent on the cellular homeostasis, provides a plausible explanation for the discrepant findings in different reports on the toxic potential of cytosolic PrP (Fioriti et al., 2005; Roucou et al., 2003). In a different study it was shown that both ${ }^{\mathrm{Ctm} P r P}$ and cytoPrP can interact with and disrupt the function of Mahogunin, a cytosolic ubiquitin ligase whose loss causes spongiform neurodegeneration in mice (Chakrabarti and Hegde, 2009).
Interestingly, it was proposed that $\mathrm{PrP}^{\mathrm{Sc}}$ might also exert its toxic potential in the cytosol.Tabrizi and colleagues showed that $\beta$-sheet-rich conformers of recombinant PrP and semi-purified $\mathrm{PrPSc}^{\mathrm{Sc}}$ from prion-infected mouse brains inhibited the $26 \mathrm{~S}$ proteasome in vitro. Moreover, proteasomal activity was decreased in prion-infected cells and in scrapiediseased mouse brain (Kristiansen et al., 2007). This study not only might help to unravel pathophysiological mechanisms in prion diseases, it also supports the notion that oligomeric species rather than larger amyloid fibrils are the harmful species, a concept that was previously suggested for different neurodegenerative diseases (rev. in (Caughey and Lansbury, 2003; Haass and Selkoe, 2007). It will now be interesting to see how oligomeric $\mathrm{PrP}^{\mathrm{Sc}}$ might translocate into the cytosol of scrapie-infected cells and how proteasomal impairment contributes to neuronal cell death in human prion diseases.

\section{Future directions}

To elucidate the mystery of a self-propagating protein conformer causing transmissible neurodegenerative diseases is a challenging mission, however, research on the prion protein has even more to offer. Transgenic mouse models paved the way for the intriguing concept that the infectious particle and the neurotoxic agent in prion diseases might be two distinct species. The existence of discrete conformers would also explain the phenomenon of sub-clinical prion infection (Hill et al., 2000). The question remains whether neurodegenerative diseases induced by neurotoxic PrP mutants in the absence of infectious prion propagation are genuine models for naturally occurring prion diseases. However, the established animal and cell culture models are extremely valuable to address an essential question in neurodegenerative disease research: How do aberrant protein conformers activate toxic signaling pathways in neuronal cells?

In addition to disease-related features, basic research on the prion protein provided new insight into cellular pathways of general interest. For example, studies employing PrP helped to reveal that the ribosome-nascent chain complex attached to the translocon complex is more dynamic than previously appreciated and that a co-translocational regulation of ER import provides an effcient mechanism to control loading of the ER with secretory pathway proteins. After all, understanding the cellular biology of diseaseassociated proteins is the essential prerequisite to exlore pathomechanistic events and to develop new therapeutic strategies.

\section{Acknowledgements}

Work of the authors was supported by grants from the Deutsche Forschungsgemeinschaft (SFB 596), the Max Planck Society, ForPrion, NeuroPrion and the BMBF.

\section{References}

Aguzzi, A., and Polymenidou, M. (2004). Mammalian prion biology: one century of evolving concepts. Cell 116, 313-327.

Amthauer, R., Kodukula, K., Gerber, L., and Udenfriend, S. (1993). Evidence that the putative COOH-terminal signal transamidase involved in glycosylphosphatidylinositol protein synthesis is present in the endoplasmic reticulum. Proc Natl Acad Sci U S A 90, 3973-3977. 
Ashok, A., and Hegde, R.S. (2009). Selective processing and metabolism of disease-causing mutant prion proteins. PLoS Pathog 5, e1000479.

Baumann, F., Tolnay, M., Brabeck, C., Pahnke, J., Kloz, U., Niemann, H.H., Heikenwalder, M., Rulicke, T., Burkle, A., and Aguzzi, A. (2007). Lethal recessive myelin toxicity of prion protein lacking its central domain. Embo $\mathrm{J} 26$, 538-547.

Blochberger, T.C., Cooper, C., Peretz, D., Tatzelt, J., Griffith, O.H., Baldwin, M.A., and Prusiner, S.B. (1997). Prion protein expression in Chinese hamster ovary cells using a glutamine synthetase selection and amplification system. Protein Eng 10, 1465-1473.

Bolton, D.C., McKinley, M.P., and Prusiner, S.B. (1982). Identification of a protein that purifies with the scrapie prion. Science 218, 1309-1311.

Brandner, S., Isenmann, S., Raeber, A., Fischer, M., Sailer, A., Kobayashi, Y., Marino, S., Weissmann, C., and Aguzzi, A. (1996). Normal host prion protein necessary for scrapie-induced neurotoxicity. Nature 379, 339-343.

Brown, D.R., Schmidt, B., and Kretzschmar, H.A. (1996). Role of microglia and host prion protein in neurotoxicity of a prion protein fragment. Nature 380, 345-347.

Caughey, B., and Lansbury, P.T. (2003). Protofibrils, pores, fibrils, and neurodegeneration: separating the responsible protein aggregates from the innocent bystanders. Annu Rev Neurosci 26, 267-298.

Caughey, B.W., Dong, A., Bhat, K.S., Ernst, D., Hayes, S.F., and Caughey, W.S. (1991). Secondary structure analysis of the scrapie-associated protein PrP 27-30 in water by infrared spectroscopy. Biochemistry 30, 7672-7680.

Chakrabarti, O., and Hegde, R.S. (2009). Functional depletion of mahogunin by cytosolically exposed prion protein contributes to neurodegeneration. Cell 137, 1136-1147.

Chesebro, B. (2003). Introduction to the transmissible spongiform encephalopathies or prion diseases. British medical bulletin $66,1-20$.

Chesebro, B., Trifilo, M., Race, R., Meade-White, K., Teng, C., LaCasse, R., Raymond, L., Favara, C., Baron, G., Priola, S., et al. (2005). Anchorless prion protein results in infectious amyloid disease without clinical scrapie. Science 308, 1435-1439.

Chiesa, R., Piccardo, P., Ghetti, B., and Harris, D.A. (1998). Neurological illness in transgenic mice expressing a prion protein with an insertional mutation. Neuron 21 , 1339-1351.

Ciechanover, A., and Brundin, P. (2003). The ubiquitin proteasome system in neurodegenerative diseases: sometimes the chicken, sometimes the egg. Neuron 40 , 427-446.

Ciechanover, A., Orian, A., and Schwartz, A.L. (2000). Ubiquitin-mediated proteolysis: biological regulation via destruction. Bioessays 22, 442-451.

Collinge, J. (2001). Prion diseases of humans and animals: their causes and molecular basis. Annu Rev Neurosci 24, 519-550.

Deli, M.A., Sakaguchi, S., Nakaoke, R., Abraham, C.S., Takahata, H., Kopacek, J., Shigematsu, K., Katamine, S., and Niwa, M. (2000). PrP fragment 106-126 is toxic to cerebral endothelial cells expressing $\operatorname{PrP}(\mathrm{C})$. Neuroreport 11, 3931-3936.
Donne, D.G., Viles, J.H., Groth, D., Mehlhorn, I., James, T.L., Cohen, F.E., Prusiner, S.B., Wright, P.E., and Dyson, H.J. (1997). Structure of the recombinant full-length hamster prion protein $\operatorname{PrP}(29-231)$ : the $\mathrm{N}$ terminus is highly flexible. Proc Natl Acad Sci USA 94, 13452-13457.

Drisaldi, B., Stewart, R.S., Adles, C., Stewart, L.R., Quaglio, E., Biasini, E., Fioriti, L., Chiesa, R., and Harris, D.A. (2003). Mutant PrP Is Delayed in Its Exit from the Neither Wild-type nor Mutant PrP Undergoes Proteasomal Degradation. J Biol Chem 278, 21732-21743.

Eisenhaber, B., Bork, P., and Eisenhaber, F. (1998). Sequence properties of GPI-anchored proteins near the omega-site: constraints for the polypeptide binding site of the putative transamidase. Protein Eng 11, 1155-1161.

Ellgaard, L., and Helenius, A. (2003). Quality control in the endoplasmic reticulum. Nat Rev Mol Cell Biol 4, 181-191.

Englund, P.T. (1993). The structure and biosynthesis of glycosyl phosphatidylinositol protein anchors. Annu Rev Biochem 62, 121-138.

Ferguson, M.A.J., and Williams, A.F. (1988). Cell-surface anchoring of protein via glycosyl-phosphatidylinositol structures. Annu Rev Biochem 57, 285-320.

Fioriti, L., Dossena, S., Stewart, L.R., Stewart, R.S., Harris, D.A., Forloni, G., and Chiesa, R. (2005). Cytosolic prion protein ( $\mathrm{PrP}$ ) is not toxic in N2a cells and primary neurons expressing pathogenic PrP mutations. J Biol Chem 280, 11320-11328.

Flechsig, E., Hegyi, I., Leimeroth, R., Zuniga, A., Rossi, D., Cozzio, A., Schwarz, P., Rulicke, T., Gotz, J., Aguzzi, A., et al. (2003). Expression of truncated PrP targeted to Purkinje cells of PrP knockout mice causes Purkinje cell death and ataxia. Embo J 22, 3095-3101.

Fons, R.D., Bogert, B.A., and Hegde, R.S. (2003). Substratespecific function of the translocon-associated protein complex during translocation across the ER membrane. J Cell Biol 160, 529-539.

Forloni, G., Angeretti, N., Chiesa, R., Monzani, E., Salmona, M., Bugiani, O., and Tagliavini, F. (1993). Neurotoxicity of a prion protein fragment. Nature 362, 543-546.

Gilmore, R., Blobel, G., and Walter, P. (1982a). Protein translocation across the endoplasmic reticulum. I. Detection in the microsomal membrane of a receptor for the signal recognition particle. J Cell Biol 95, 463-469.

Gilmore, R., Walter, P., and Blobel, G. (1982b). Protein translocation across the endoplasmic reticulum. II. Isolation and characterization of the signal recognition particle receptor. J Cell Biol 95, 470-477.

Gu, Y., Singh, A., Bose, S., and Singh, N. (2008). Pathogenic mutations in the glycosylphosphatidylinositol signal peptide of PrP modulate its topology in neuroblastoma cells. Mol Cell Neurosci 37, 647-656.

Haass, C., and Selkoe, D.J. (2007). Soluble protein oligomers in neurodegeneration: lessons from the Alzheimer's amyloid beta-peptide. Nat Rev Mol Cell Biol 8, 101-112.

Haïk, S., Peyrin, J.M., Lins, L., Rosseneu, M.Y., Brasseur, R., Langeveld, J.P., Tagliavini, F., Deslys, J.P., Lasmézas, C., and Dormont, D. (2000). Neurotoxicity of the Putative Transmembrane Domain of the Prion Protein. Neurobiol Dis 7, 644-656. 
Hegde, R.S., and Bernstein, H.D. (2006). The surprising complexity of signal sequences. Trends Biochem Sci 31, 563-571.

Hegde, R.S., Mastrianni, J.A., Scott, M.R., DeFea, K.A., Tremblay, P., Torchia, M., DeArmond, S.J., Prusiner, S.B., and Lingappa, V.R. (1998). A transmembrane form of the prion protein in neurodegenerative disease. Science 279 , 827-834.

Heller, U., Winklhofer, K.F., Heske, J., Reintjes, A., and Tatzelt, J. (2003). Post-translational import of the prion protein into the endoplasmic reticulum interferes with cell viability: a critical role for the putative transmembrane domain. J Biol Chem 278, 36139-36147.

Hershko, A., and Ciechanover, A. (1998). The ubiquitin system. Annu Rev Biochem 67, 425-479.

Heske, J., Heller, U., Winklhofer, K.F., and Tatzelt, J. (2004). The $\mathrm{C}$-terminal domain of the prion protein is necessary and sufficient for import into the endoplasmic reticulum. J Biol Chem 279, 5435-5443.

Hill, A.F., Joiner, S., Linehan, J., Desbruslais, M., Lantos, P.L., and Collinge, J. (2000). Species-barrier-independent prion replication in apparently resistant species. Proc Natl Acad Sci U S A 97, 10248-10253.

Holscher, C., Bach, U.C., and Dobberstein, B. (2001). Prion protein contains a second endoplasmic reticulum targeting signal sequence located at its $\mathrm{C}$ terminus. J Biol Chem 276, 13388-13394.

Kang, S.W., Rane, N.S., Kim, S.J., Garrison, J.L., Taunton, J., and Hegde, R.S. (2006). Substrate-specific translocational attenuation during ER stress defines a pre-emptive quality control pathway. Cell 127, 999-1013.

Kim, S.J., and Hegde, R.S. (2002). Cotranslational partitioning of nascent prion protein into multiple populations at the translocation channel. Mol Biol Cell 13, 3775-3786.

Kim, S.J., Rahbar, R., and Hegde, R.S. (2001). Combinatorial control of prion protein biogenesis by the signal sequence and transmembrane domain. J Biol Chem 276, 26132-26140.

Kodukula, K., Gerber, L.D., Amthauer, R., Brink, L., and Udenfriend, S. (1993). Biosynthesis of glycosylphosphatidylinositol (GPI)-anchored membrane proteins in intact cells: specific amino acid requirements adjacent to the site of cleavage and GPI attachment. J Cell Biol 120, 657-664.

Kornfeld, R., and Kornfeld, S. (1985). Assembly of asparagine-linked oligosaccharides. Annu Rev Biochem 54, 631-664.

Kristiansen, M., Deriziotis, P., Dimcheff, D.E., Jackson, G.S., Ovaa, H., Naumann, H., Clarke, A.R., van Leeuwen, F.W., Menendez-Benito, V., Dantuma, N.P., et al. (2007). Disease-associated prion protein oligomers inhibit the 26 S proteasome. Mol Cell 26, 175-188.

Kurschner, C., and Morgan, J.I. (1995). The cellular prion protein (PrP) selectively binds to $\mathrm{Bcl}-2$ in the yeast twohybrid system. Brain Res Mol Brain Res 30, 165-168.

Kurschner, C., and Morgan, J.I. (1996). Analysis of interaction sites in homo- and heteromeric complexes containing Bcl-2 family members and the cellular prion protein. Brain Res Mol Brain Res 37, 249-258.

Li, A., Christensen, H.M., Stewart, L.R., Roth, K.A., Chiesa, R., and Harris, D.A. (2007). Neonatal lethality in transgenic mice expressing prion protein with a deletion of residues 105-125. Embo J 26, 548-558.

Lin, B., Kolluri, S.K., Lin, F., Liu, W., Han, Y.H., Cao, X., Dawson, M.I., Reed, J.C., and Zhang, X.K. (2004). Conversion of $\mathrm{Bcl}-2$ from protector to killer by interaction with nuclear orphan receptor Nur77/TR3. Cell 116, 527-540.

Lopez, C.D., Yost, C.S., Prusiner, S.B., Myers, R.M., and Lingappa, V.R. (1990). Unusual topogenic sequence directs prion protein biogenesis. Science 248, 226-229.

Ma, J., and Lindquist, S. (2001). Wild-type PrP and a mutant associated with prion disease are subject to retrograde transport and proteasome degradation. Proc Natl Acad Sci U S A 98, 14955-14960.

Ma, J., Wollmann, R., and Lindquist, S. (2002). Neurotoxicity and neurodegeneration when PrP accumulates in the cytosol. Science 298, 1781-1785.

Malhotra, J.D., and Kaufman, R.J. (2007). The endoplasmic reticulum and the unfolded protein response. Semin Cell Dev Biol 18, 716-731.

Mallucci, G., Dickinson, A., Linehan, J., Klohn, P.C., Brandner, S., and Collinge, J. (2003). Depleting neuronal PrP in prion infection prevents disease and reverses spongiosis. Science 302, 871-874.

Martoglio, B., and Dobberstein, B. (1998). Signal sequences: more than just greasy peptides. Trends Cell Biol 8, 410-415.

Meusser, B., Hirsch, C., Jarosch, E., and Sommer, T. (2005). ERAD: the long road to destruction. Nat Cell Biol 7, 766-772.

Meyer, D.I., and Dobberstein, B. (1980). Identification and characterization of a membrane component essential for the translocation of nascent proteins across the membrane of the endoplasmic reticulum. J Cell Biol 87, 503-508.

Meyer, R.K., McKinley, M.P., Bowman, K.A., Braunfeld, M.B., Barry, R.A., and Prusiner, S.B. (1986). Separation and properties of cellular and scrapie prion proteins. Proc Natl Acad Sci USA 83, 2310-2314.

Miesbauer, M., Pfeiffer, N.V., Rambold, A.S., Muller, V., Kiachopoulos, S., Winklhofer, K.F., and Tatzelt, J. (2009). Alpha-helical domains promote translocation of intrinsically disordered polypeptides into the endoplasmic reticulum. J Biol Chem 284, 24384-24393.

Mironov, A.J., Latawiec, D., Wille, H., BouzamondoBernstein, E., Legname, G., Williamson, R.A., Burton, D., DeArmond, S.J., Prusiner, S.B., and Peters, P.J. (2003). Cytosolic prion protein in neurons. J Neurosci 23, 7183-7193.

Moran, P., Raab, H., Kohr, W.J., and Caras, I.W. (1991). Glycophospholipid membrane anchor attachment. Molecular analysis of the cleavage/attachment site. J Biol Chem 266, 1250-1257.

Morimoto, R.I. (2008). Proteotoxic stress and inducible chaperone networks in neurodegenerative disease and aging. Genes Dev 22, 1427-1438.

Muramoto, T., DeArmond, S.J., Scott, M., Telling, G.C., Cohen, F.E., and Prusiner, S.B. (1997). Heritable disorder resembling neuronal storage disease in mice expressing prion protein with deletion of an a-helix. Nat Med 3, 750-755.

Nakatsukasa, K., and Brodsky, J.L. (2008). The recognition and retrotranslocation of misfolded proteins from the endoplasmic reticulum. Traffic 9, 861-870. 
Nuoffer, C., Horvath, A., and Riezman, H. (1993). Analysis of thesequencerequirementsforglycosylphosphatidylinositol anchoring of Saccharomyces cerevisiae Gas1 protein. J Biol Chem 268, 10558-10563.

Nuoffer, C., Jeno, P., Conzelmann, A., and Riezman, H. (1991). Determinants for glycophospholipid anchoring of the Saccharomyces cerevisiae GAS1 protein to the plasma membrane. Mol Cell Biol 11, 27-37.

Orsi, A., Fioriti, L., Chiesa, R., and Sitia, R. (2006). Conditions of endoplasmic reticulum stress favor the accumulation of cytosolic prion protein. J Biol Chem 281, 30431-30438.

Oyadomari, S., Yun, C., Fisher, E.A., Kreglinger, N., Kreibich, G., Oyadomari, M., Harding, H.P., Goodman, A.G., Harant, H., Garrison, J.L., et al. (2006). Cotranslocational degradation protects the stressed endoplasmic reticulum from protein overload. Cell 126, 727-739.

Pan, K.-M., Baldwin, M., Nguyen, J., Gasset, M., Serban, A., Groth, D., Mehlhorn, I., Huang, Z., Fletterick, R.J., Cohen, F.E., et al. (1993). Conversion of a-helices into b-sheets features in the formation of the scrapie prion proteins. Proc Natl Acad Sci USA 90, 10962-10966.

Pickart, C.M. (2001). Mechanisms underlying ubiquitination. Annu Rev Biochem 70, 503-533.

Prusiner, S.B., Scott, M.R., DeArmond, S.J., and Cohen, F.E. (1998). Prion protein biology. Cell 93, 337-348.

Rambold, A.S., Miesbauer, M., Rapaport, D., Bartke, T., Baier, M., Winklhofer, K.F., and Tatzelt, J. (2006). Association of $\mathrm{Bcl}-2$ with misfolded prion protein is linked to the toxic potential of cytosolic PrP. Mol Biol Cell 17, 3356-3368.

Rambold, A.S., Müller, V., Ron, U., Ben-Tal, N., Winklhofer, K.F., and Tatzelt, J. (2008). Stress-protective activity of prion protein is corrupted by scrapie-prions. Embo $\mathrm{J} 27$, 1974-1984.

Rane, N.S., Yonkovich, J.L., and Hegde, R.S. (2004). Protection from cytosolic prion protein toxicity by modulation of protein translocation. Embo J 23, 4550-4559.

Riek, R., Hornemann, S., Wider, G., Billeter, M., Glockshuber, R., and Wuthrich, K. (1996). NMR structure of the mouse prion protein domain $\operatorname{PrP}(121-321)$. Nature 382, 180-182.

Riek, R., Hornemann, S., Wider, G., Glockshuber, R., and Wuthrich, K. (1997). NMR characterization of the fulllength recombinant murine prion protein, $\operatorname{mPrP}(23-231)$. FEBS Lett 413, 282-288.

Rogers, M., Yehiely, F., Scott, M., and Prusiner, S.B. (1993). Conversion of truncated and elongated prion proteins into the scrapie isoform in cultured cells. Proc Natl Acad Sci U S A 90, 3182-3186.

Ron, D., and Walter, P. (2007). Signal integration in the endoplasmic reticulum unfolded protein response. Nat Rev Mol Cell Biol 8, 519-529.

Roucou, X., Guo, Q., Zhang, Y., Goodyer, C.G., and LeBlanc, A.C. (2003). Cytosolic prion protein is not toxic and protects against Bax-mediated cell death in human primary neurons. J Biol Chem 278, 40877-40881.

Rutkowski, D.T., Kang, S.W., Goodman, A.G., Garrison, J.L., Taunton, J., Katze, M.G., Kaufman, R.J., and Hegde, R.S. (2007). The role of p58IPK in protecting the stressed endoplasmic reticulum. Mol Biol Cell 18, 3681-3691.

Shmerling, D., Hegyi, I., Fischer, M., Blättler, T., Brandner, S., Götz, J., Rülicke, T., Flechsig, E., Cozzio, A., von Mehring, C., et al. (1998). Expression of animo-terminally truncated PrP in the mouse leading to ataxia and specific cerebellar lesions. Cell 93, 203-214.

Stahl, N., Borchelt, D.R., Hsiao, K., and Prusiner, S.B. (1987). Scrapie prion protein contains a phosphatidylinositol glycolipid. Cell 51, 229-240.

Stewart, R.S., Drisaldi, B., and Harris, D.A. (2001). A Transmembrane Form of the Prion Protein Contains an Uncleaved Signal Peptide and Is Retained in the Endoplasmic Reticululm. Mol Biol Cell 12, 881-889.

Stewart, R.S., Piccardo, P., Ghetti, B., and Harris, D.A. (2005). Neurodegenerative illness in transgenic mice expressing a transmembrane form of the prion protein. $\mathrm{J}$ Neurosci 25, 3469-3477.

Tagliavini, F., Prelli, F., Verga, L., Giaccone, G., Sarma, R., Gorevic, P., Ghetti, B., Passerini, F., Ghibaudi, E., Forloni, G., et al. (1993). Synthetic peptides homologous to prion protein residues 106-147 form amyloid-like fibrils in vitro. Proc Natl Acad Sci U S A 90, 9678-9682.

Tatzelt, J., and Winklhofer, K.F. (2004). Folding and misfolding of the prion protein in the secretory pathway. Amyloid 11, 162-172.

Udenfriend, S., and Kodukula, K. (1995). How glycosylphosphatidylinositol-anchored membrane proteins are made. Annu Rev Biochem 64, 563-591.

Uelhoff, A., Tatzelt, J., Aguzzi, A., Winklhofer, K.F., and Haass, C. (2005). A pathogenic PrP mutation and doppel interfere with polarized sorting of the prion protein. J Biol Chem 280, 5137-5140.

von Heijne, G. (1985). Signal sequences. The limits of variation. Journal of molecular biology 184, 99-105.

Walmsley, A.R., Zeng, F.N., and Hooper, N.M. (2001). Membrane topology influences $\mathrm{N}$-glycosylation of the prion protein. Embo J 20, 703-712.

Walter, P., and Blobel, G. (1980). Purification of a membrane-associated protein complex required for protein translocation across the endoplasmic reticulum. Proc Natl Acad Sci U S A 77, 7112-7116.

Walter, P., and Blobel, G. (1982). Signal recognition particle contains a 7S RNA essential for protein translocation across the endoplasmic reticulum. Nature 299, 691-698.

Walter, P., Gilmore, R., and Blobel, G. (1984). Protein translocation across the endoplasmic reticulum. Cell 38, $5-8$.

Wang, X., Bowers, S.L., Wang, F., Pu, X.A., Nelson, R.J., and $\mathrm{Ma}$, J. (2009). Cytoplasmic prion protein induces forebrain neurotoxicity. Biochim Biophys Acta.

Wang, X., Wang, F., Arterburn, L., Wollmann, R., and Ma, J. (2006). The interaction between cytoplasmic prion protein and the hydrophobic lipid core of membrane correlates with neurotoxicity. J Biol Chem 281, 13559-13565.

Wang, X., Wang, F., Sy, M.S., and Ma, J. (2005). Calpain and other cytosolic proteases can contribute to the degradation of retro-translocated prion protein in the cytosol. J Biol Chem 280, 317-325.

Weissmann, C., Fischer, M., Raeber, A., Büeler, H., Sailer, A., Shmerling, D., Rülicke, T., Brandner, S., and Aguzzi, A. (1996). The role of PrP in pathogenesis of experimental scrapie. Cold Spring Harb Symp Quant Biol 61, 511-522.

Winklhofer, K.F., Heske, J., Heller, U., Reintjes, A., Muranji, W., Moarefi, I., and Tatzelt, J. (2003). Determinants of the in vivo-folding of the prion protein: a bipartite function of helix 1 in folding and aggregation. J Biol Chem 278, 14961-14970. 
Winklhofer, K.F., Tatzelt, J., and Haass, C. (2008). The two faces of protein misfolding: Gain and loss of function in neurodegenerative diseases. EMBO J 27, 336-349.

Yedidia, Y., Horonchik, L., Tzaban, S., Yanai, A., and Taraboulos, A. (2001). Proteasomes and ubiquitin are involved in the turnover of the wild-type prion protein. Embo J 20, 5383-5391.
Yost, C.S., Lopez, C.D., Prusiner, S.B., Myers, R.M., and Lingappa, V.R. (1990). Non-hydrophobic extracytoplasmic determinant of stop transfer in the prion protein. Nature 343, 669-672.

Zanusso, G., Petersen, R.B., Jin, T., Jing, Y., Kanoush, R., Ferrari, S., Gambetti, P., and Singh, N. (1999). Proteasomal degradation and $\mathrm{N}$-terminal protease resistance of the codon 145 mutant prion protein. $\mathrm{J}$ Biol Chem 274, 23396-23404. 


\section{Further Reading}

Caister Academic Press is a leading academic publisher of advanced texts in microbiology, molecular biology and medical research. Full details of all our publications at caister.com

- MALDI-TOF Mass Spectrometry in Microbiology Edited by: M Kostrzewa, S Schubert (2016) www.caister.com/malditof

- Aspergillus and Penicillium in the Post-genomic Era Edited by: RP Vries, IB Gelber, MR Andersen (2016) www.caister.com/aspergillus2

- The Bacteriocins: Current Knowledge and Future Prospects Edited by: RL Dorit, SM Roy, MA Riley (2016)

www.caister.com/bacteriocins

- Omics in Plant Disease Resistance Edited by: V Bhadauria (2016) www.caister.com/opd

- Acidophiles: Life in Extremely Acidic Environments Edited by: R Quatrini, DB Johnson (2016) www.caister.com/acidophiles

- Climate Change and Microbial Ecology: Current Research and Future Trend

Edited by: J Marxsen (2016)

www.caister.com/climate

- Biofilms in Bioremediation: Current Research and Emerging Technologies

Edited by: G Lear (2016)

www.caister.com/biorem

- Microalgae: Current Research and Applications Edited by: MN Tsaloglou (2016) www.caister.com/microalgae

- Gas Plasma Sterilization in Microbiology: Theory, Applications, Pitfalls and New Perspectives Edited by: H Shintani, A Sakudo (2016) www.caister.com/gasplasma

- Virus Evolution: Current Research and Future Directions Edited by: SC Weaver, M Denison, M Roossinck, et al. (2016) www.caister.com/virusevol

- Arboviruses: Molecular Biology, Evolution and Control Edited by: N Vasilakis, DJ Gubler (2016) www.caister.com/arbo

- Shigella: Molecular and Cellular Biology Edited by: WD Picking, WL Picking (2016) www.caister.com/shigella

-Aquatic Biofilms: Ecology, Water Quality and Wastewater Treatment

Edited by: AM Romaní, H Guasch, MD Balaguer (2016)

www.caister.com/aquaticbiofilms

- Alphaviruses: Current Biology

Edited by: S Mahalingam, L Herrero, B Herring (2016)

www.caister.com/alpha

- Thermophilic Microorganisms

Edited by: F Li (2015)

www.caister.com/thermophile
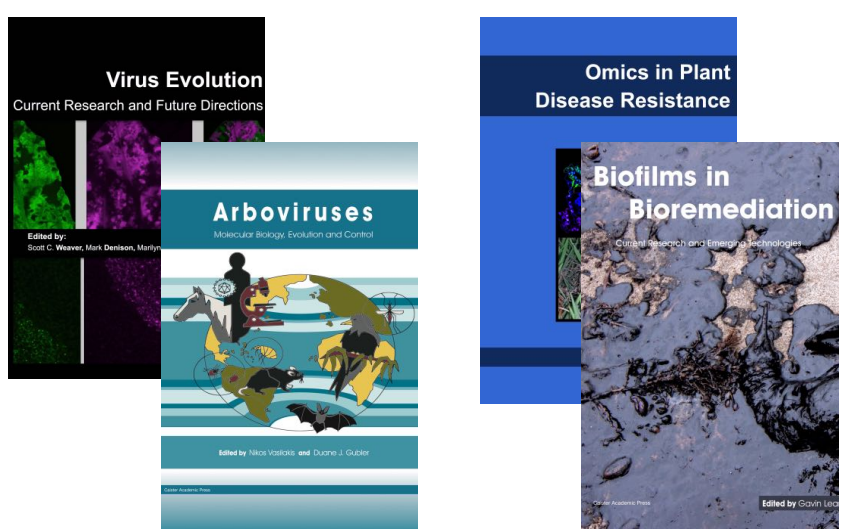
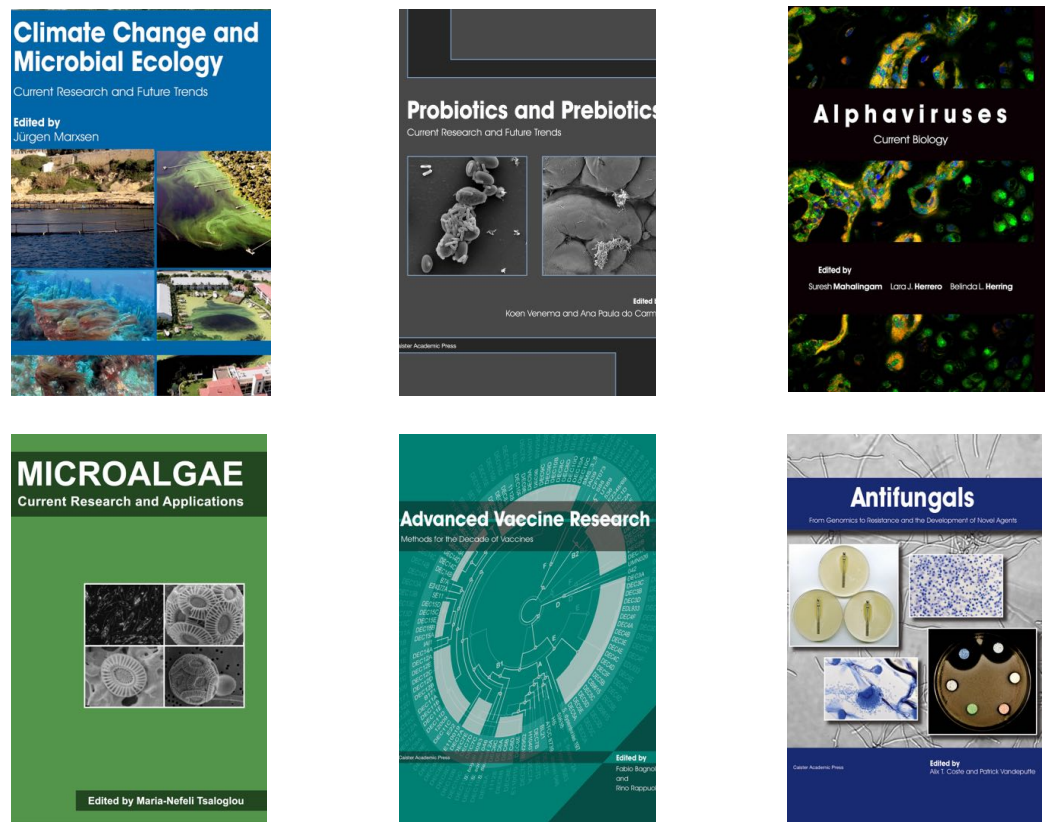

- Flow Cytometry in Microbiology: Technology and Applications Edited by: MG Wilkinson (2015) www.caister.com/flow

- Probiotics and Prebiotics: Current Research and Future Trends Edited by: K Venema, AP Carmo (2015) www.caister.com/probiotics

- Epigenetics: Current Research and Emerging Trends Edited by: BP Chadwick (2015) www.caister.com/epigenetics2015

- Corynebacterium glutamicum: From Systems Biology to Biotechnological Applications

Edited by: A Burkovski (2015)

www.caister.com/cory2

- Advanced Vaccine Research Methods for the Decade of Vaccines

Edited by: F Bagnoli, R Rappuoli (2015)

www.caister.com/vaccines

- Antifungals: From Genomics to Resistance and the Development of Novel Agents

Edited by: AT Coste, P Vandeputte (2015)

www.caister.com/antifungals

- Bacteria-Plant Interactions: Advanced Research and Future Trends Edited by: J Murillo, BA Vinatzer, RW Jackson, et al. (2015) www.caister.com/bacteria-plant

\section{- Aeromonas}

Edited by: J Graf (2015)

www.caister.com/aeromonas

- Antibiotics: Current Innovations and Future Trends

Edited by: S Sánchez, AL Demain (2015)

www.caister.com/antibiotics

- Leishmania: Current Biology and Contro Edited by: S Adak, R Datta (2015) www.caister.com/leish2

- Acanthamoeba: Biology and Pathogenesis (2nd edition) Author: NA Khan (2015)

www.caister.com/acanthamoeba2

- Microarrays: Current Technology, Innovations and Applications Edited by: Z He (2014)

www.caister.com/microarrays2

- Metagenomics of the Microbial Nitrogen Cycle: Theory, Methods and Applications

Edited by: D Marco (2014)

www.caister.com/n2 